\title{
TGF-Beta Receptor Type-1
}

National Cancer Institute

\section{Source}

National Cancer Institute. TGF-Beta Receptor Type-1. NCI Thesaurus. Code C30098.

T GF-beta receptor type-1 (503 aa, $\sim 56 \mathrm{kDa}$ ) is encoded by the human T GFBR1 gene. This protein plays a role in both T GF-beta-dependent signaling and serine/threonine phosphorylation. 